\title{
Crossing of potato in Tajikistan
}

\section{Kurbonali Partoev*, Naimov Safarali and Melikov Kurbonali}

Institute of Botany, Plant Physiology and Genetics, Academy of Sciences, Republic of Tajikistan.

Accepted 15 February, 2017

\begin{abstract}
This article shows that in conditions of high mountains of Tajikistan (at height more than $2700 \mathrm{~m}$ above sea level), fertility of pollen grains of Solanum tuberosum L. varies from 5 to $97 \%$. Among clones of potato studied, only 5 to $9.7 \%$ had viable pollen grains. Also, in conditions of a mountain zone, big polylithism was established for qualitative traits such as flower coloring, anther coloring and forms of stamen columns of flower of potato. As a result of carrying out crossing of varieties of potato, more than $6 \mathrm{~kg}$ of hybrid berries $\mathrm{F}_{1}$ were obtained. These hybrid seeds will be used in breeding and genetic research works in the future.
\end{abstract}

Keywords: Breeding, crossing, pollen vitality, hybridization, clone, Tajikistan.

*Corresponding author. E-mail: pkurbonali@mail.ru.

\section{INTRODUCTION}

Potato tubers are valuable food products for most people in the world, and in many regions are considered a "second bread". The agricultural environment of mountainous areas of Tajikistan situated at an altitude of more than 1800 meters above sea level, make it possible to grow good and quality harvest of potato. Under these cool mountainous conditions, potato plants are of little affection, have intensive bloom, and form a lot of berries and botanic seeds.

During the researches made in different soil and climatic conditions a number of scientists (Perlova, 1958; Balashev, 1968; Lebedeva, 1970; Bukasov and Kameraz, 1972; Yashina et al., 1983; Mumindjanov, 2003; Shpaar, 2004; Kiru, 2007; Partoev et al., 2007; Carli et al., 2008; and Partoev et al., 2008) have ascertained the significance of breeding pair selection and locality of crossbreeding, so as to get good results of potato hybridization.

According to Mendiburu and Peloquin (1976), Frankel and Galun (1977), Kaushik et al. (1996), Gopal (1994), Kumar and Gopal (2003), Pandey et al. (2005), Gupta et al. (2004) and Luthra et al. (2006) from India, success of selective and genetic work aimed at nurture of new perspective grades, depend to a large extent on pollen grain fertility and vitality when conducting different crossing between grades and species of potato.

Thus, on basis of above researchers' work analysis and our experience on potato crossbreeding obtained in India this year, for the first time in the highland of Tajikistan we have begun to research the rate of pollen grain fertility and to cross different grades and hybrids of potato and the results of this researchers brining in this brochure.

\section{MATERIALS AND METHODS}

To determine the vitality of potato pollen grains, the following types of work were prepared and carried out:

1. Make acetocarmine solution, dropping bottle, forceps and needle ready for potato pollen release.

2. Remove flower pistil using forceps.

3. Pour out the pollen on the slide in the acetocarmine drop by shaking the stamen filament of the flower.

4. Cover the acetocarmine and pollen mixture with a glass sheet.

5 . The ready preparation is to be examined through the microscope in 3 to 5 minutes.

6. The quantity of acetocarmine coloured pollen grains (both fertile - vital pollen grains and yellow pollen grains - sterile or unviable grains) should be counted in three or five microscopic fields.

7. The counted quantity of coloured and uncoloured pollen grains is to be recorded into the log book.

Pollen vitality was analyzed in three terms: on July 20 (the beginning of blooming period), on August 1 (mass blooming period) and on August 10 (the end of blooming period) in 2009. In each term the pollen of five plants of each sample was taken, 15 plants in total. Fertile (vital) and sterile (unviable) pollen grains were counted in three microscope fields with increasing of $8 \times 7$ on the microscopes MBC-9 and MBC-10 and with increasing of $20 \times 7$ on 
the microscope MBU-4A.

As a material for research, 62 clones and varieties of potato from the International Potato Center (CIP) in the network of plant gene pool investigation in the republics of Central Asia and the Caucasus were used. Also the collection of potato samples were obtained from the Institute of Plant Physiology and Phytogenetics, Academy of Sciences, Republic of Tajikistan and Social Organization "Tukhmiparvar", from VIR in 90th years of the last century. Planting was carried out on March 13, 2009 at an altitude of 2700 meters above sea level, in the field station of Social Organization "Tukhmiparvar" situated in the Jirgital region, Sari-Kendja village, Muksu jamoat, Republic of Tajikistan.

Also straight and back crosses of different potato grades and species were carried out in order to obtain first generation hybrids. For conducting potato grades crossbreeding after 3 p.m. emasculation of maternal plant flowers (removal of flower stamen filament with forceps) was made. After 4 p.m. we plucked paternal plant flowers, removed their pistils and kept them in a Petri dish at the room temperature from 4 p.m. to 9 a.m. of the next day.

In the morning, inside the room we shook stamen filaments with anthers using forceps and needle and picked the pollen into the glass Petri dishes of small size. The picked pollen was used for pollination of emasculated flowers by touching the pistil head with the picked pollen of paternal flowers. After pollination we attached a paper label indicating hybrid combination (maternal form $\mathrm{x}$ paternal form) and the date of crossbreeding written in pencil to the stem. The number of pollinated flowers was recorded into the potato crossbreeding log book in compliance with the dates of pollination. All statistical dates $\left(\mathrm{X}, \mathrm{S}, \mathrm{S}_{\mathrm{x}}, \mathrm{V}, \%, \mathrm{LSD}_{05}\right)$ processing were done according to Dospekhov (1985).

\section{RESULTS AND DISCUSSION}

Investigations concerning identification of potato pollen grain fertility have been conducted in Jirgital region at an altitude of 2700 meters above sea level where an experimental plot of the Social Organization "Tukhmiparvar" and the Institute of Plant Physiology and Phytogenetics of the Academy of Sciences of the Republic of Tajikistan. Fertile (vital) potato pollen grains placed in the acetocarmine drop are coloured and turned red. As to sterile pollen grains, they are not coloured and will have yellow colouring. Their number can be easily counted through the microscope (Figure 1).

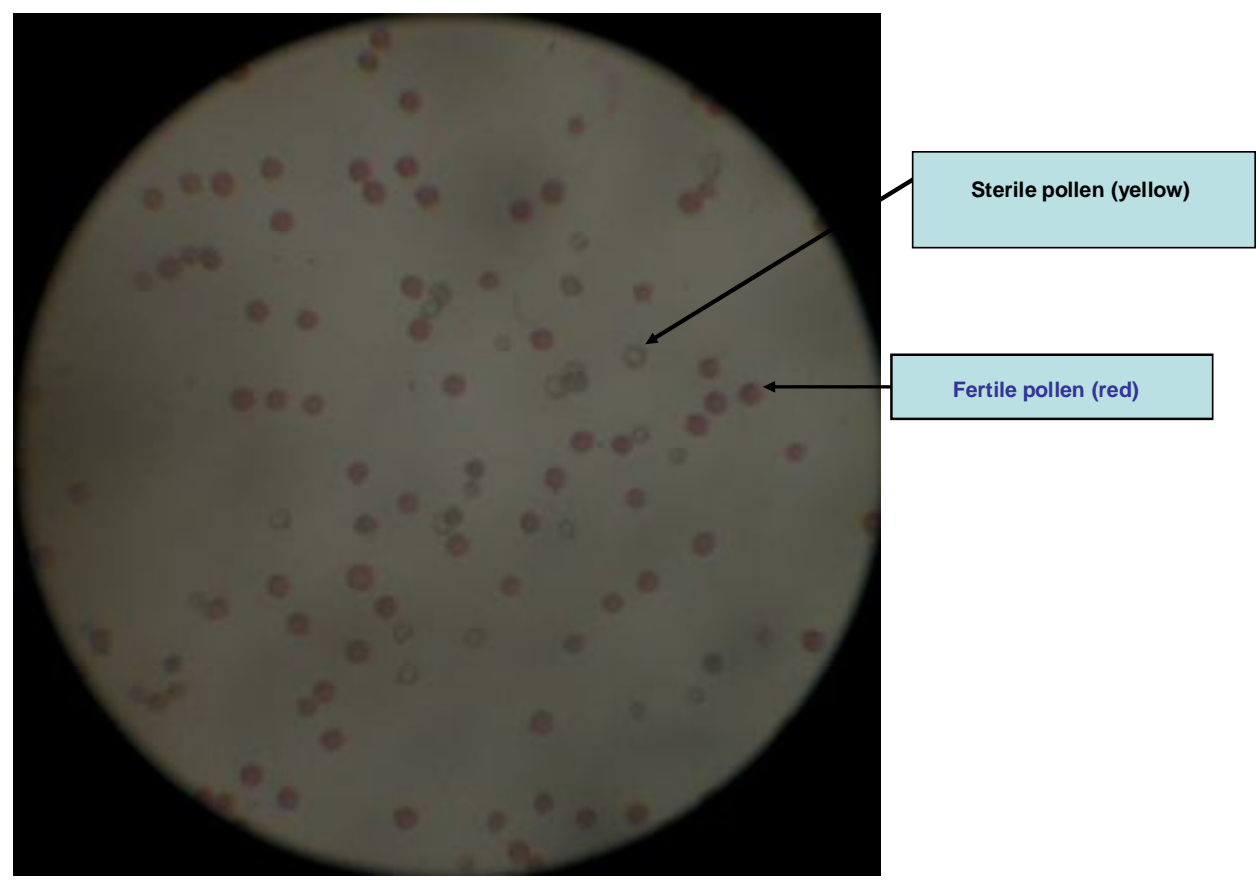

Figure 1. Sterile (yellow) and fertile (red) potato pollen grains indicate the magnification.

Pollen grain fertility of potato clones and grades in highland environment of our republic is genotypically specific. Most of the examined clones and grades have more than 80 to $97 \%$ of fertile (vital) pollen grains. At the same time it is necessary to note that pollen grain fertility of some potato grades makes only 5 to $10 \%$ (Table 1 ).

Among potato varieties cultivated in the mountainous area, Cardinal grade had the lowest percentage of fertile pollen grains with an average of $26.5 \%$, while the new perspective Dusti grade had the highest (95.2\%). This grade was raised by the scientists of the Institute of Plant Physiology and Phytogenetics, Academy of Sciences, Republic of Tajikistan; the Social Organization "Tukhmiparvar"; and the International Potato Centre (CIP). This year the grade has been given to the Tajik State Commission on quality testing and grade 
Table 1. Percentage of fertile pollen grains of potato grades in highland environment (Jirgital region at an altitude of 2700 meters above sea level).

\begin{tabular}{|c|c|c|c|c|c|}
\hline \multirow{2}{*}{ No. } & \multirow{2}{*}{ Varieties of potato } & \multicolumn{3}{|c|}{ Sampling dates } & \multirow{2}{*}{ Mean } \\
\hline & & Jul. 20 & Aug. 1 & Aug. 10 & \\
\hline 1 & Cardinal & 28.0 & 24.4 & 27.1 & 26.5 \\
\hline 2 & Zarina & 79.2 & 83.0 & 84.0 & 82.1 \\
\hline 3 & Dusti & 95.0 & 96.6 & 94.0 & 95.2 \\
\hline 4 & Faizabad & 85.9 & 86.0 & 84.1 & 85.3 \\
\hline 5 & Zhukovski & 85.7 & 93.3 & 90.3 & 89.8 \\
\hline 6 & Condor & 83.0 & 86.3 & 85.0 & 84.8 \\
\hline 7 & Picasso & 86.4 & 85.2 & 84.1 & 85.2 \\
\hline 8 & Hybrid 22 & 84.5 & 87.5 & 90.4 & 87.5 \\
\hline 9 & Hybrid 23 & 64.7 & 74.9 & 98.2 & 79.3 \\
\hline 10 & Clone $27 / 5$ & 64.7 & 63.5 & 63.6 & 63.9 \\
\hline 11 & Clone $30 / 9$ & 76.7 & 77.0 & 78.9 & 77.5 \\
\hline 12 & Clone $36 / 6$ & 66.7 & 68.3 & 70.3 & 68.4 \\
\hline 13 & Clone $37 / 2$ & 84.1 & 86.2 & 93.8 & 88.0 \\
\hline 14 & Clone $40 / 1$ & 79.3 & 81.0 & 87.3 & 82.5 \\
\hline 15 & Clone $47 / 4$ & 93.4 & 91.5 & 85.9 & 90.3 \\
\hline 16 & Clone $47 / 8$ & 83.3 & 85.1 & 89.8 & 86.1 \\
\hline 17 & Clone $47 / 11$ & 91.7 & 90.2 & 89.7 & 90.5 \\
\hline 18 & Clone 50/7 & 85.9 & 85.5 & 86.7 & 86.0 \\
\hline 19 & Clone 50/9 & 87.4 & 87.6 & 84.1 & 86.4 \\
\hline 20 & Clone 52/6 & 75.8 & 73.6 & 74.6 & 74.7 \\
\hline 21 & Clone 1 & 94.4 & 88.4 & 97.5 & 93.4 \\
\hline 22 & Clone 2 & 5.6 & 7.3 & 6.7 & 6.5 \\
\hline 23 & Clone 3 & 5.3 & 6.0 & 8.0 & 6.4 \\
\hline 24 & Clone 4 & 62.0 & 63.0 & 60.5 & 61.8 \\
\hline 25 & Clone 7 & 5.7 & 5.2 & 6.3 & 5.7 \\
\hline 26 & Clone 8 & 95.0 & 97.9 & 98.0 & 97.0 \\
\hline 27 & Clone 11 & 11.5 & 12.0 & 11.3 & 11.6 \\
\hline 28 & Clone 13 & 95.7 & 97.5 & 90.0 & 94.4 \\
\hline 29 & Clone 14 & 10.9 & 11.6 & 8.0 & 10.2 \\
\hline 30 & Clone 15 & 5.6 & 7.2 & 7.3 & 6.7 \\
\hline 31 & Clone 18 & 81.0 & 80.5 & 75.7 & 79.1 \\
\hline 32 & Clone 21 & 87.2 & 94.7 & 82.7 & 88.2 \\
\hline 33 & Clone 22 & 85.8 & 84.9 & 91.5 & 87.4 \\
\hline 34 & Clone 24 & 47.5 & 38.8 & 42.6 & 43.0 \\
\hline 35 & Clone 25 & 94.5 & 98.0 & 90.9 & 94.5 \\
\hline 36 & Clone 26 & 75.4 & 73.1 & 75.1 & 74.5 \\
\hline 37 & Clone 27 & 90.0 & 88.6 & 92.1 & 90.2 \\
\hline 38 & Clone 40 & 32.0 & 35.9 & 33.8 & 33.9 \\
\hline 39 & Clone 42 & 73.0 & 70.8 & 72.9 & 72.2 \\
\hline 40 & Clone 43 & 83.5 & 84.8 & 75.6 & 81.3 \\
\hline 41 & Clone 45 & 96.8 & 88.9 & 86.2 & 90.6 \\
\hline 42 & Clone 48 & 5.7 & 4.8 & 5.6 & 5.4 \\
\hline 43 & Clone 50 & 9.2 & 10.0 & 9.0 & 9.4 \\
\hline 44 & Clone 53 & 95.7 & 97.1 & 84.2 & 92.3 \\
\hline 45 & Clone 54 & 89.3 & 87.8 & 94.0 & 90.4 \\
\hline 46 & Clone 55 & 90.7 & 89.9 & 90.5 & 90.4 \\
\hline 47 & Clone 56 & 95.2 & 97.5 & 96.8 & 96.5 \\
\hline 48 & Clone 58 & 10.6 & 9.1 & 9.3 & 9.7 \\
\hline 49 & Clone 59 & 88.4 & 86.0 & 93.0 & 89.1 \\
\hline
\end{tabular}


Table 1. Continues.

\begin{tabular}{llcccc}
\hline 50 & Clone 60 & 87.6 & 89.4 & 88.1 & 88.4 \\
51 & Clone 63 & 88.8 & 82.8 & 92.1 & 87.9 \\
52 & Clone 64 & 5.0 & 6.6 & 7.0 & 6.2 \\
53 & Clone 65 & 5.2 & 4.7 & 5.4 & 5.1 \\
54 & Clone 66 & 96.6 & 95.0 & 94.0 & 95.2 \\
55 & Clone 67 & 6.0 & 7.1 & 7.1 & 6.7 \\
56 & Clone 68 & 23.6 & 25.0 & 25.0 & 24.5 \\
57 & Clone 71 & 23.9 & 21.0 & 19.8 & 21.6 \\
58 & Clone 73 & 78.0 & 76.0 & 76.5 & 76.8 \\
59 & Clone 75 & 95.4 & 94.9 & 91.9 & 94.1 \\
60 & Clone 76 & 97.9 & 85.6 & 81.1 & 88.2 \\
61 & Clone 79 & 95.3 & 89.0 & 85.4 & 89.9 \\
62 & Clone 80 & 13.0 & 11.8 & 13.0 & 12.6 \\
& & & & & \\
$\mathrm{X}$ & 64.9 & 64.7 & 64.9 & 64.8 \\
$\mathrm{~S}$ & 34.3 & 34.2 & 34.3 & 34.2 \\
$\mathrm{~S}$ & 4.3 & 4.2 & 4.2 & 4.2 \\
$\mathrm{~V}, \%$ & 52.9 & 52.8 & 52.6 & 52.5 \\
$\mathrm{LSD}$ & 8.6 & 8.4 & 8.6 & 8.5 \\
\hline
\end{tabular}

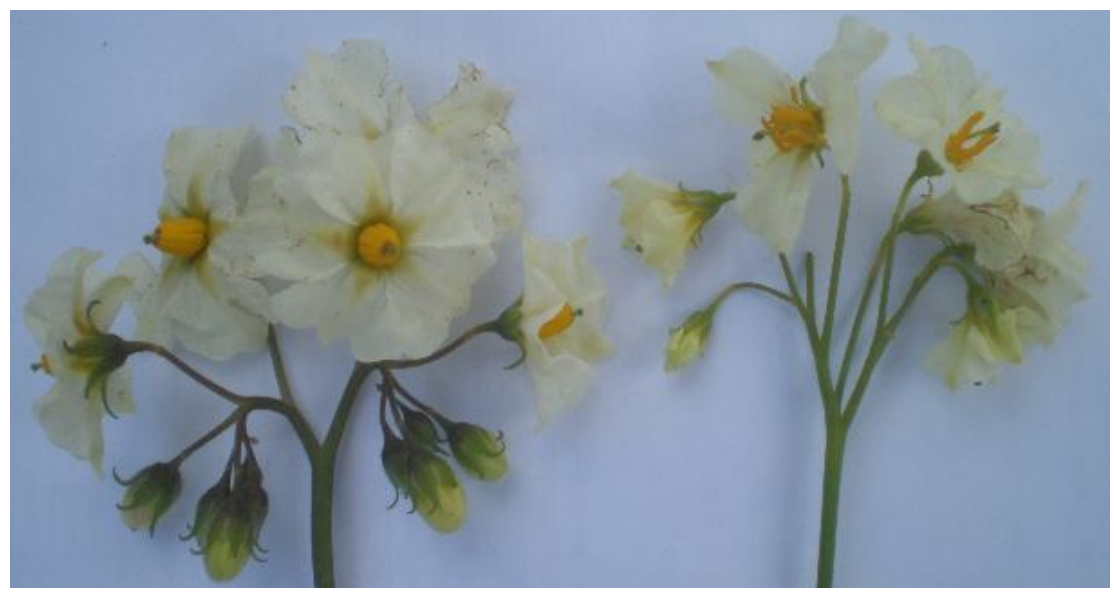

a

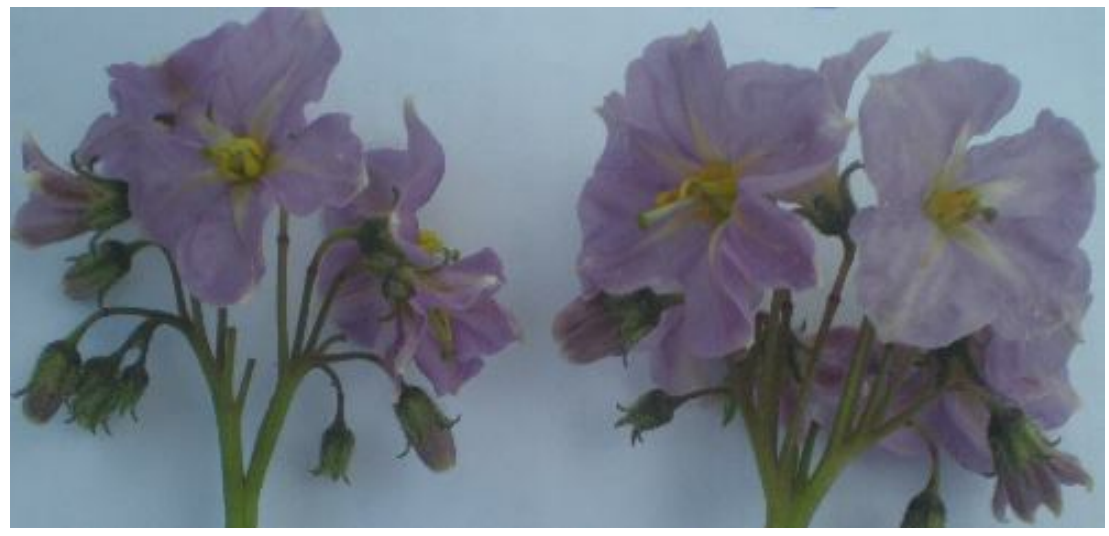

b

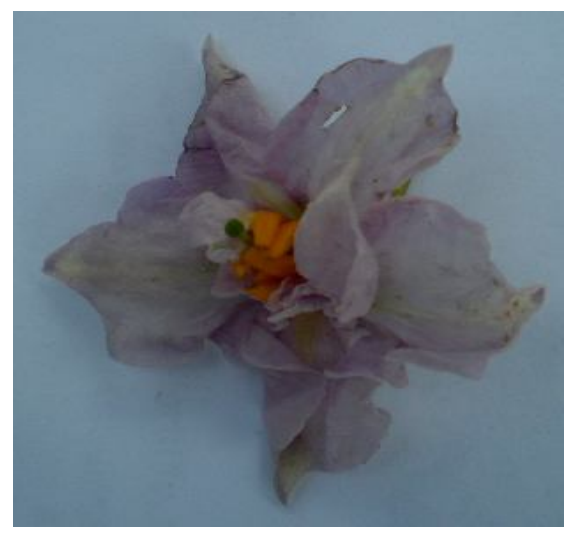

C

Figure 2. Different shapes of flowers, stamen filaments and pistils of potato clones: (a) \# 43, (b) \# 48 and (c) \# 54. 
Table 2. Pollen grain fertility (\%) in potato clones with different shape of the flower stamen filament.

\begin{tabular}{|c|c|c|c|c|c|}
\hline \multirow{2}{*}{ No. } & \multirow{2}{*}{ Varieties of potato } & \multicolumn{3}{|c|}{ Analysis implementation dates } & \multirow{2}{*}{ Mean } \\
\hline & & Jul. 20 & Aug. 1 & Aug. 10 & \\
\hline 1 & Clone 43 (plants with regular stamen filament) & 83.5 & 84.8 & 75.6 & 81.3 \\
\hline 2 & Clone 43 (plants with modified shape of stamen filament) & 45.7 & 50.1 & 47.5 & 47.8 \\
\hline 3 & Clone 48 (plants with modified shape of stamen filament) & 5.7 & 4.8 & 5.6 & 5.4 \\
\hline
\end{tabular}

Table 3. Number of pollinated flowers and set berries obtained through potato hybridization (2009).

\begin{tabular}{|c|c|c|c|c|c|c|}
\hline No. & Maternal form & Paternal form & $\begin{array}{c}\text { Number of } \\
\text { pollinated } \\
\text { flowers }\end{array}$ & Date of crossing & $\begin{array}{c}\text { Number of } \\
\text { gathered } \\
\text { berries }\end{array}$ & $\begin{array}{l}\text { Rate of berry } \\
\text { formation }\end{array}$ \\
\hline 1 & Clone 75 & Kufri Sadabakhar & 18 & Jul.19 & 0 & 0 \\
\hline 2 & Clone 76 & Kufri Jirgari & 48 & Jul.19 & 18 & 37.5 \\
\hline 3 & Clone 66 & Kufri Jiota & 30 & Jul.19 & 10 & 33.3 \\
\hline 4 & Khahadin & Kufri Arunda & 38 & Jul.19 & 3 & 7.9 \\
\hline 5 & Clone 75 & Kufri Anchan & 15 & Jul.19 & 0 & 0 \\
\hline 6 & Clone 75 & Kufri Suraya & 34 & Jul.19 & 6 & 17.6 \\
\hline 7 & Clone 59 & GTH/107 & 26 & Jul.19 & 0 & 0 \\
\hline 8 & Clone 66 & Kufri Suraya & 7 & Jul.19 & 2 & 28.6 \\
\hline 9 & Clone 76 & Mix of pollen & 29 & Jul.19 & 5 & 17.2 \\
\hline 10 & Clone 68 & Mix of pollen & 14 & Jul.19 & 0 & 0 \\
\hline 11 & Clone 63 & Mix of pollen & 12 & Jul.19 & 3 & 13.6 \\
\hline 12 & Clone 75 & Clone 76 & 25 & Jul.19 & 6 & 24.0 \\
\hline 13 & Clone 76 & Clone 75 & 22 & Jul.19 & 8 & 36.4 \\
\hline 14 & Clone 79 & Clone 66 & 7 & Jul.19 & 0 & 0 \\
\hline 15 & Zhukovski ranniy & Dusti & 72 & Jul. 21 & 0 & 0 \\
\hline 16 & Dusti & Zhukovski raniy & 15 & Jul. 21 & 0 & 0 \\
\hline 17 & Cardinal & Dusti & 70 & Jul. 21 & 3 & 43.0 \\
\hline 18 & Dusti & Cardinal & 20 & Jul. 21 & 0 & 0 \\
\hline 19 & Dusti & Condor & 191 & Jul. 21 & 83 & 43.5 \\
\hline 20 & Zarina & Dusti & 40 & Jul. 21 & 0 & 0 \\
\hline 21 & Dusti & Picasso & 44 & Jul. 21 & 17 & 38.6 \\
\hline 22 & Hybrid 23 & Dustï & 23 & Jul. 21 & 0 & 0 \\
\hline 23 & Clone 40/1 & Dusti & 22 & Jul. 21 & 1 & 4.5 \\
\hline 24 & Clone 40/1 & Cardinal & 17 & Jul. 22 & 0 & 0 \\
\hline 25 & Hybrid 22 & Dusti & 11 & Jul. 23 & 0 & 0 \\
\hline 26 & Hybrid 23 & Picasso & 53 & Jul. 23 & 0 & 0 \\
\hline 27 & Faizabad & Picasso & 127 & Jul. 23 & 41 & 32.3 \\
\hline 28 & Cardinal & Condor & 125 & Jul. 31 & 88 & 70.4 \\
\hline 29 & Cardinal & Picasso & 105 & Jul. 31 & 84 & 80.0 \\
\hline 30 & Clone 48 & Dusti & 65 & Jul. 31 & 2 & 3.1 \\
\hline 31 & Clone 40/1 & Dusti & 22 & Jul. 31 & 16 & 72.7 \\
\hline 32 & Cardinal & Dusti & 50 & Aug. 1 & 0 & 0 \\
\hline 33 & Hybrid 23 & Dusti & 85 & Aug. 1 & 0 & 0 \\
\hline 34 & Clone $40 / 1$ & Dusti & 30 & Aug. 1 & 6 & 20.0 \\
\hline 35 & Zarina & Hybrid 23 & 25 & Aug. 1 & 2 & 8.0 \\
\hline 36 & Dusti & Condor & 85 & Aug. 11 & 53 & 63.4 \\
\hline \multirow[t]{2}{*}{37} & Clone 48 & Condor & 28 & Aug. 11 & 14 & 50.0 \\
\hline & Total: & & 1650 & & 471 & 28.5 \\
\hline
\end{tabular}


protection.

It should be noted that some clones sampled individually from hybrid swarm $F_{1}$ and propagated from one plant by culture method (in-vitro plants), had stamen filaments of different shapes. For example, clones 43, 48 and 54 had different morphological attributes of stamen filaments (Figure 2). Clone 43 had plants with two types of stamen filament shape. One part of the plant had a regular stamen filament; the other part of the plant had a modified stamen filament when stamen filaments are not pressed to the pistil stem as it is with regular plants. They are detached from it and look friable.

Thus, according to the stamen filament shape among these new potato clones, we can observe definite variation. It should be noted that the rest of the morphological traits (plant and flower colour, leaf shape, evolution phenological stage and tuber colour of the examined clones) remained stable. In addition, the our researches indicated that the plants with modified shape of the stamen filament have weak yellow colour of the stamen filament and low fertility of pollen grains compared to regular plants (Table 2).

Plants with modified shape of stamen filament have considerably less fertile pollen grains compared to those with regular stamen (Table 2). The sign of cytoplasmic male sterility is greatly detected with clone 48 where pollen grain fertility was only $5.4 \%$. Along with it, we have ascertained that although many potato clones have regular stamen filament shape and bright yellow colouring of the stamen filament and anther, their index of fertility is very low. They are clones $2,3,7,15,50,58,64$, 65 , and 67 that have only 5.1 to $9.7 \%$ of fertile pollen grains. These clones can serve as a good base line for potato breeding through straight crossing (without anther removal), and for obtaining botanic seeds without flower emasculation. Thus, specific potato clones with male sterility sign have been defined.

As a result of potato hybridization carried out in Jirgital region from July 19 to August 11 (1650 crosses) by early September (Table 3 ) regular berries $F_{1}$ (Figure 3 ) were obtained, which seeds will be studied in the future.

\section{CONCLUSIONS}

For the first time, study of pollen grain fertility and hybridization of potato varieties has been carried out in the mountainous area of Tajikistan.

The degree of pollen grain fertility and the variability of this genetic trait among 62 potato samples have been determined (5 to $97 \%$ ).

Some potato clones have great variability based on the flower and anther color as well as on the shape of the stamen filament.

Ten potato clones were selected based on the low quantity of fertile pollen grains (5.1 to $9.7 \%$ ).

Potato variety Cardinal grade showed the lowest percentage (26.5) of fertile pollen grains, while Dusti

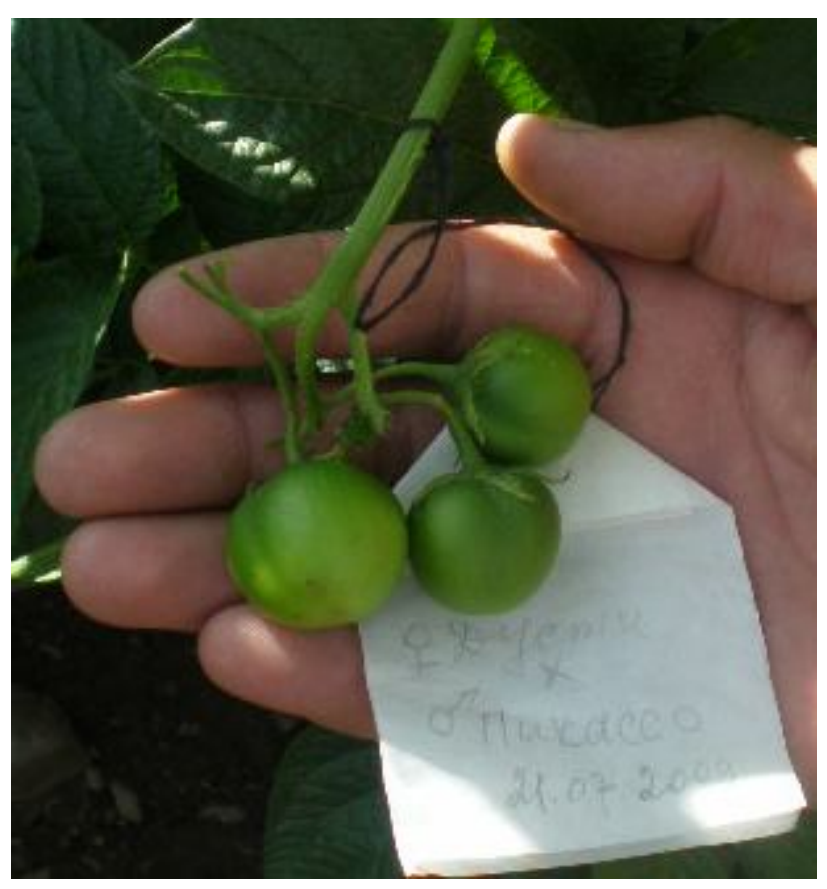

Figure 3. Potato hybrid berries, obtained through Dusti $x$ Picasso grades crossing.

grade showed the highest (95.2\%).

Six $\mathrm{kg}$ of hybrid berries were obtained from crosses of potato varieties and hybrids.

\section{REFERENCES}

Balashev NN, 1968. Growing of potato and vegetables. Moscow City, p.366.

Bukasov SM, Kameraz AY, 1972. Selection and seed farming of potato. Leningrad City, p.359.

Carli C, Khalikov D, Yuldashev F, Partoev K, Melikov K, Naimov S, 2008. Resent advances in potato research and development in Central Asia. Abstracts Global Potato Conference, Delhi City, p. 3132.

Dospekhov BA, 1985. Field experimental methodic. Moscow, $334 \mathrm{p}$.

Frankel R, Galun E, 1977. Pollination mechanisms, reproduction and plant breeding. Springer Verlag, Berlin-Heidelberg. New York, USA. p. 35-78.

Gopal J, 1994. Flowering behavior, male sterility and berry setting in tetraploid Solanum tuberosum germplasm. Euphytica, 72: 133-142.

Gupta VK, Thakur KC, Kumar S, Pandey SK, Sah U, 2004. True Potato Seed - An Alternative Technology for Potato Production in Northeastern Hill Region. CPRI, Shimla City, p. 1- 21.

Kaushik SK, Birhman RK, Singh BP, Gopal J, 1996. Combining ability and heterosis for field resistance to late blight in potato. In. National Symposium on Molecular Approaches in Plant Disease Management, CPRI, Shimla city, 14-15 November, p. 31.

Kiru SD, 2007. Outcomes and prospects of the world potato collection research. Genetic resources of cultivated plants in XXI century. The II Vavilov International Conference Reports Theses. St. Petersburg, p. 474-476.

Kumar R, Gopal J, 2003. Combining ability of andigena accessions for yield components and tuber dry matter in third clonal generation. $J$ Indian Potato Assoc, 30: 3-4.

Lebedeva NV, 1970. To the question of mountainous potato seed farming in the northern Tajikistan. Newslett Sci Tech Informat, 8: 47- 
50.

Luthra SK, Pandey SK, Singh BP, Kang GS, Singh SV, Pandey PC, 2006. Potato Breeding in India. Central Potato Research Institute, Shimla, p. 3-71.

Mendiburu AO, Peloquin SJ, 1976. Sexual polyploidization and deploidization: Some terminology and definitions. Ther Appl Genet, 48: 137-143.

Mumindjanov KA, 2003. Physiological and biotechnological approach to selection and seed farming of potato. Dushanbe city, p.126.

Pandey SK, Singh SV, Chakrabarti SK, Manivel P, 2005. New potato hybrids. Central Potato Research Institute, Shimla, pp. 3-44.

Partoev K, Karimov B, Sulangov M, Melikov K, 2007. Study of potato varieties in different ecological conditions of Tajikistan. Genetic resources of cultivated plants in XXI century. The II Vavilov International Conference Reports Theses. Sankt-Petersburg, p. 329331.

Partoev K, Sulangov M, Melikov K, Naimov S, Aliev K, Davlatnazarova Z, Karimov B, Mukimov T, 2008. Potato research and development in Tajikistan. Abstracts Global Potato Conference, Delhi city, pp. 34-35.

Perlova RL, 1958. Potato species habit in different regions of the USSR. Publishing House of the Academiy of Sciences. Moscow city, p. 238.

Shpaar D, 2004. Potato. Torzhok city, "Variant", p. 461.

Yashina IM, Sklyarova IP, Kiryukhin VP, 1983. Recommendations on development of potato grade model for non-black soil area of the country and physiological and biochemical methods of selection material assessment in practical selection. Moscow city., p. 48-54.
Citation: Partoev k, Safarali N, Kurbonali M, 2017. Crossing of potato in Tajikistan. Net J Agric Sci, 5(1): 16-22. 